\title{
BUGIS AND MADURA MIGRATION IN NUSANTARA: Religiosity, Harmony, and Identity from Eastern Indonesia
}

\author{
Ismail Suardi Wekke, "Suyatno Ladigi, "* and Reevany Bustami ${ }^{\text {*स }}$ \\ * Sekolah Tinggi Agama Islam Negeri (STAIN) Sorong, West Papua, \\ Indonesia \\ ** Universiti Sultan Zainal Abidin Terengganu, Malaysia \\ *** Universiti Sains Malaysia Penang, Malaysia \\ E-mail: ismail@stain-sorong.ac.id
}

\section{Abstract}

The Buginese and Madurese are well known as fierce sailors and are openhearted ethnics in Indonesia. It seems that they have their typical characters and identities compared to the other ethnics in Indonesia. Their characters and identities become part of their life, including in economic, social customs or even when they immigrated to a new place. This phenomenology study tried to explain the behavior of Buginese and the people of Madurese who immigrated to Papua. The study also would seek to explore beyond migration of the Bugis and Madurese in Papua. This article was conducted in Papua to assess the patterns of migration and community interaction of Bugis and Madurese with other communities. The study findings revealed that Buginese and Madurese seem similar among others in terms of economic activity, mastery in the field of politics, and social role in the community. Besides, with their capacity, it has a role in religious activities which they always carry out in their environment. By not making it as a mission of deployment religious activities, but rather only to defend their religious understanding in a way that it would be limited just to the internal environment. It seems both the Buginese and Madurese firmly have a 
connection to the Islamic identity factors that are part of their religious expression.

Di Indonesia, orang Bugis dan Madura telah lama dikenal sebagai suku pelaut yang tangguh juga berhati terbuka. Keunikan kedua etnis tersebut tampaknya memiliki banyak persamaan dalam karakter dan identitas jika dibandingkan dengan etnis lain di Indonesia. Karakter dan identitas menjadi kebiasaan dari kehidupan mereka mereka tersebut yang membuat mereka unik, termasuk dalam kebiasaan ekonomi, sosial atau bahkan ketika mereka berimigrasi ke tempat baru. Studi fenomenologi ini mencoba menjelaskan perilaku orang Bugis dan orang Madura yang berimigrasi ke Papua. Studi ini juga berupaya mengeksplorasi di balik migrasi orang Bugis dan Madura ke Papua. Studi ini dilakukan di Papua untuk menilai pola migrasi dan interaksi masyarakat Bugis dan Madura dengan komunitas lain di Papua. Temuan penelitian mengungkapkan orang Bugis dan Madura tampak hampir serupa dalam hal aktivitas ekonomi, penguasaan di bidang politik, dan peran sosial dalam masyarakat. Kedua etnis tersebut juga memiliki pola berinteraksi dan membangun hubungan dengan komunitas lainnya dalam kegiatan keagamaan yang selalu mereka lakukan di lingkungan mereka sendiri. Dengan tidak menjadikannya sebagai misi penyebaran kegiatan keagamaan, tetapi hanya untuk mempertahankan pemahaman agama mereka di lingkungan internal. Tampaknya orang Bugis dan Madura memiliki hubungan kuat dengan faktor identitas Islam yang merupakan bagian dari jati diri sekaligus menunjukkan ekspresi keagamaan mereka.

Keywords: harmony; identity; migration; religious; tradition

Received: June 28, 2018; Accepted: June 17, 2019

\section{Introduction}

Merchandising to Makassar, Kaili, Donggala, Kema, Ternate, and Banda in the eastern part of Indonesia has been going on ever since the era of Raffles in the year of 1818 (Poelinggomang 1991). Therefore, the population of the eastern part has been interacting in a trade with ships sailing up from Java, Kalimantan, and Sumatra. While Peninsular of Malaysia had already familiar with Bugis traders started from the 15th century (Rachmat 1977). This bidirectional relationship between the East 
and West regions of Nusantara has been running and lasts up until now. With the equipment and facilities increasingly advanced of shipping, then the access that connects the island of Java and Sulawesi, and Papua is getting easier to conduct. The other way round the delivery of goods and mobility of the population has been done in a two-way; including the means of transportation with the use of air transportation. The movement of people from one island to another in Indonesia is growing.

Although the cruising and the existence of modern transportation have already developed as advanced as they are currently, it does not mean that the traditional cruising stops just a meaning of old technology. Sailors and Bugis ships craftsman are traditionally kept on growing. Just like in Fakfak \& Kaimana, the southern part of the Papua Island, traditional fishers came to catch fish. There also grow shipyards in some coastal cities that became the center of shipbuilding. They are continually developing the technology for shipping used traditionally. Although they maintain a tradition obtained from the ancestors and their parents, the willingness to innovate for the sake of efficiency of marine traffic continues to grow simultaneously. Although modern ships are available, the choice of traditional ships also remains dominant. With these conditions, the potential for sentiment may occur at the intended destination. As the people of Taiwan and Hong Kong, they also experienced problems in adapting to the environment as the place to stay (Chiang 2011; Ley 2010).

Population distribution reached eastern Indonesia, one of which comes from government programs in the form of the transmigration program. However, some quarters chose to migrate to Papua without government programs. With no further implementation of the transmigration program, the spread of the population increased from time to time. The most considerable growth population of Papua and West Papua precisely is due to the movement of people from other islands of Indonesia. While in some cities such as Timika, Manokwari, Sorong, Merauke, Sentani, and Jayapura, population growth is also due to the needs of professional workers filled by outsider workers.

Among communities who inhabited the island of Papua are Bugis and Madura. Although not the majority, both communities play a substantial role in a dwelling on their lives. They are also a significant part of the development of society. They become a buffer for the communities; moving the local economy forward. Not only in urban but also up to the inlands. In remote areas, they distribute goods. Indeed, not only because of 
the economic benefits alone but also the existence of a humanitarian spirit to help the lives of others. By providing necessities of daily life, they also keep life to continue. Initiatives and movements performed contribute to maintaining unity in the context of the nation state.

Bugis and Madura's societies show different patterns of migration. There were also differences in perspectives in looking at how migration and the existence of transmigration. Both of them have differences in treating the relationship with the land where they were given births and the origin of their family traits. On the other hand, they also have an identity and a choice of the religious majority. Although not thoroughly, the number of people who accept Islam as their religions is more dominant than other religions accepted by the people living in that particular area. Aside from these differences, there also have similarities. With various motives of migration, the two ethnics have made the migration to be part of their lives. A culture that they practice always accepts that migration is a tradition and supposedly for some matters, it is mostly, yet, a pride to be held high.

Migration of Bugis people is a practice that has become one part of their traditions. Philosophically, they look at this tradition as a need for them to hold migrations in order to strengthen their lives. The word "kegisimonro soro lopie", kositutomallabuse'ngereng" (where there is a boat harbored, there shall be a life to be strengthened). With such word, it essentially means that there was a long history of experiences from ancestors down to the present traits of families. It is believed by the people of Bugis that it has made the migration itself as a form of a chance to obtain a better living. For that matter, migration activities are part of those various traditions that is not strange anymore, it is also becoming a primary choice and for various reason that resides behind the choice made. Furthermore, with this migration to be held, it symbolizes that in the culture, it has been going on for time to time.

One of the Bugis ethnics is called Wajo. They have a perspective that tends to put forth the migration activity and as a choice of options given. Freedom is seen as a right of every human being. Thus when that particular freedom could not be achieved, then the choice to move from place to place is something that happens in general. A set of legal advice that has become the guideline stated in a statement of "Maradeka to WajoAde'eminapopuwang" (The people of Wajo are independent, only legal entities are applied). If somehow a condition is not giving liberation anymore and a chance to live a life of liberation is no more, then they would try to fight for that freedom 
in other places; although they have to realize that they must leave their birthplace. Maintaining a place where they were born in is not essential if they would not be able to acquire freedom and liberation in living a life.

For Bugis society, religion is an accepted part of everyday lives. Thus, religion remains an important part. Although it is not explicitly religious activity still they are trying to make all the activities done in the nuances of religious. The historical record of Mattulada shows that the entire land of Bugis already accepted Islam since 1612 (Mattulada 1998). Thus, institutions that practiced in the community have a particular joint on the teachings of Islam.

Furthermore, in a teaching program, technology has an important role (Wekke and Hamid 2013). While there is currently held will be retained if it does not conflict with Islamic theology. Openness to accept the most recent developments continue to grow. At the same time, uphold the consciousness of the past. The merger between them becomes a character of its own, which firmly holds the tradition but at the same time accepting and willing to open up to things that become the state of demands. These characteristics are formed because of the similarities between Islamic principles with the culture practiced before the advent of Islam. Likewise, the willingness is to make Islam the only guideline to implement.

While the people of Madura have made Islam as the primary guide; things that are contrary to Islamic values are specifically considered (Pribadi 2018). As a theological aspect in the case that does not allow building a statue; thus, the Madura community avoids explicitly the urge to get involved in the construction of statues. Including the absence of sculptures in their homes and not even tolerate the construction of a statue in urban areas. Constancy in the spirit of this sharia holds and provides support for everyday life; including the persistence in attempting economic affairs. This firm belief also becomes an integral part when dealing with other individuals. They treat others like themselves. Then put pride upon one's heart as part of the price to be preserved, maintained, and could even be a gamble of life itself (Wiyata 2002). Therefore, social relationships are established in the form of an award from one to another.

Also, a study of migration related to Islamic matters needs to be done to explain how people's behavior of Bugis and the people of Madura encountering with different religious communities. The study seeks to answer the question of how migration is done by the Bugis and Madurese 
community in Papua. This question is then connected to the Islamic identity factors that are part of religious expression. This study was conducted in Papua to assess patterns of migration and community interaction of Bugis and Madurese with other communities. Therefore, this study specifically examines the patterns of migration of Bugis and Madurese community in Papua.

Moreover, the study about Papua in the eastern part of Maluku Island has not received the attention of many researchers. Therefore, the article identifies the migration of the Bugis people to Papua Island. Furthermore, in connection with the Madurese were also parts of the migration to Papua Island. Besides, this article concerns the relevant aspects of ethnicities migration to Papua, which was not explicitly discussed by the previous researchers.

\section{Bugis and Madurese Encounter in Muslim Identity}

Bugis society is known for its migration tradition. One of the early studies conducted by Naim explains the five tribes in Indonesia who migrated as their tradition; one of them is Buginese (Naim 1972). With the data in 1930, Abidin suggests the data of three major tribes inhabiting South Sulawesi as the people always come in contact with the sea, namely Bugis, Makassar, and Mandar (Abidin 1983). Thus, for the Bugis, movement in the form of malleke 'dapureng (moving to another kitchen) is not exactly new, but the practice has been carried out since their interaction with the sea began to flourish.

Identities formed are not merely only the outcomes of such production but also construction. The existence of a particular naming based on the circumstances of each. With adaptation and environmental dynamics that exist in Papua, Bugis and Madurese community express themselves. Furthermore, it would be accepted by other communities as part of the acceptance of other groups. The identity will never be a final form but continuously ongoing associated with the social conditions. Berger explains at least two processes that occur in the formation of identity, externalization, and internalization. Both are then faced with the reality experienced by each (Berger 1963) while the difference in the value system adopted with what he/she saw is to be done by accepting differences. While what is believed to be a value only applied in a limited environment. However, this action does not erode the identity held down for a long time. There ought to be integration occurring by disregarding conflicts and 
tension (Reuveny 2007). By avoiding the distinction as a potential conflict, it would be used as a supporting attempt for the community unification. Without the need to release the held value of each; but trying to appreciate the differences. Furthermore, this at the same time is being an opportunity to confirm its identity.

Adaptation to the sea for the Bugis people is done by not only on a matter of law, boat engines, and sailing equipment; but also their ability that has reached the skills to sail the sea. Research of navigation by the Bugis community (Ammarell 2008) says that with their social context into an idea of how the delivery of goods within the business is carried out by the Bugis traders via boat. The idea, perception, and understanding of space developed in association with the sea make the navigation system as a guide for the modernization of the boat as part of the context of Indonesia today. In particular, a part of the manuscript called La Galigo illustrates the cruise conducted by the Sawerigading around the world (Rahman 2006). It can be interpreted that the love of the sea also to the realm of literature. As well as a picture that sea is a part of life that is not strange. Instead, to write it in the form of literature indicates that there is a full understanding of the existence of the sea itself.

Ricklefs et al. illustrate that the Bugis people are devout Muslims toward religious teachings. In Ricklefs note that was using the data precisely from the year of 1600-1800, conflict, and such tense are the reasons for large-scale migration. They migrated to the Peninsula of Malaya and Siam. Likewise, they reach toward the East to Ternate, Tidore, Hitu, and Hoamoal (Ricklefs et al. 2013). Migration studies of Bugis to Peninsula of Malaysia received attention with adequate research by scholars. The research of Bugis in Eastern of Indonesia is still in the form of a preliminary manuscript not written in the form of research. Acciaioli only writes about debts and kinship systems (Acciaioli 2009). The research was conducted in the area of Lindu Lake, Central Sulawesi. Moreover, the study of the Bugis with larger areas towards Eastern of the island of Sulawesi was not found in detail. Similarly, the work of Soleh describes the eastern part of Indonesia; and even then only to the extent of Ambon (Soleh 2010).

The research found that on the Madurese focused on traditional farmers (Kuntowijoyo 1980). Whereas the actual migration culture is a common practice carried out by the Madurese community; although it has been started from around East Java, then reaching to Jakarta. Note by Husson that the continuity of the Madurese community has been going on 
for eight centuries (Husson 1997). The study describes explicitly the life of a fisherman in the community structure of Madura run by Mintaroem and Farisi. In the two explanations stated that the life of the Madurese fishermen was in the form of a group and never stand alone as separate individuals. The relationship between workers and employers are not relationships that are built by superiors and subordinates but rather a form of a family (Mintaroem and Farisi 2001). Similarly, the explanation of de Jonge that concluded that the marine fisheries are carried out by the Madurese was more because of a side job alone (de Jonge 1989). This condition is the picture of the past of Madurese person.

Kiai (religious leader) become an essential part of the life of the Madurese. It shows that Islam is no longer limited to mere ritual, but to reach a close relationship between the leader and the community. Four key figures that serve as a role model and the duty to obey orders resided for everyone. Buppa (father), Babbu (mother), Guru (teacher), Rato (head of government) is a structure that should be placed higher in the hierarchy of life (Wiyata 2003), as well as with the growth of brotherhood culture. It is due to the similarity or resemblance conformity with the primordial elements, especially in the belief system. Religiosity is placed as the main character. They hold on to the religion and at the same firmly attached to cultural traditions but prioritize religion as something significant. Entrenchment Islamic sharia then revealed as "As badly as possible of the Madurese in religion, if there is an insult of the religion (Islam) then they remain furious"; moreover, if they were to be judged as not a Muslim. Madurese and Islam unity is the couple that has been integrated. Thus when there is a Madurese who does not embrace Islam, then this consequently would mean that he or she denies himself/herself as a Madurese (Subaharianto et al. 2004).

\section{Bugis and Madura Migration in Nusantara}

A migration activity undertaken by the Bugis people to Sumatra was encouraged by political factors. It was still in the throes of the struggle for independence. With the chaos caused by the colonizers caused them to choose to move to an environment that can provide a better life. In the new place that later they then get a significant role to gain political power and empire building that today then developed into the country of Malaysia. While the migration in other studies indicates that there was a private mission borne that their arrival was much of social factors. 
Meanwhile, migration can also occur due to economic factors. With these three factors, political, religious, and economic, to be a part of situational. While some developments also indicate that education is also an important part that led to the emergence of migration. Some groups from Hidayatullah took corners of Papua to establish Islamic boarding schools (pesantren). They run educational institutions and at the same time as a means of religious communication (dakwah), including agriculture and plantations skills for people undertaking education. Every single city or regency in Papua Island already establishes a Hidayatullah institution. Another group of people after graduated from Darul Da'wah wal Irsyad (DDI), they started the DDI school to maintain the form of Islamic education.

Bugis study in Papua more focused on the discussion of marriage (Wekke 2012). Other research examines explicitly only speech acts that took place in the religious message in Sorong City (Wekke 2014). While Yusuf and Wekke research tend to discuss the thinking of scholars from Bugis. This study examines explicitly the Bugis language interpretation manuscript compiled by the Majelis Ulama Indonesia (MUI) of South Sulawesi (Yusuf and Wekke, 2013). Although the work was published in the context of South Sulawesi, only uses Bugis language and does not include other ethnic languages in South Sulawesi. Thus the study of the manuscript is the study of interpretation by using Bugis language. It is in line with Wekke; he said that we could understand a manuscript because we interpret the language of the manuscript (Wekke 2016).

A specific publication work concerning Bugis migration was written by Sani with a focus of study on innovative migration by the Bugis community (Sani 2005). The writing was more into analyzing regarding causes of the migration carried out by the community of Bugis. However, the writing does not make a study specifically on places of the migration carried out by the community of Bugis at that time. Meanwhile, a writing which is specifically concerning migration written by Kesuma only illustrates the migration carried out by the Community of Bugis in Malaysia precisely in Johor. That study illustrates the wave of migration carried out by the community of Bugis to Johor which then, later on, would be merged with the people of Melayu (Kesuma 2004). If we were to look at that fact from the frame of Southeast Asia, several things would differentiate the patterns of Bugis community spread and the Madurese with the existence of their people in Singapore and Malaysia. Whereas in Papua, two 
communities of Madurese and Bugis, actually had similarities of nationality. However, still, in a different context of the communities which were heterogeneous and that became a group of people who express their feeling dynamically.

\section{Bugis in Papua}

The existence of the Bugis people who move to Papua does not occur simply in our current time alone. Some of them have lived since birth. However, they are still trying to maintain the identity and emotional connection with their ancestors. Nevertheless, they have already interacted with the local community and then have transformed into a new identity; not only the Bugis but also the Bugis of Papua. All the attributes of life bear become an integral part of Papua situation itself. They then identify themselves as the Bugis, but with their presence in Papua specifically later called themselves with Bugis of Papua. Once it becomes a symbol that Papua has become an integral part of their identity.

For internal purposes, Bugis society then organizes themselves in Kerukunan Keluarga Sulawesi Selatan (KKSS). However, this organization stands not only in Papua but in all regions of Indonesia. It is led directly by the permanent secretariat in Jakarta. To explain the unity of the Bugis people in the sight of KKSS does not only happen in Papua but already in a national context. KKSS existence is nothing more than a community organization just for gathering. The various diverse political backgrounds, professions, and social activities of its members immerse themselves in the organization built for the sake of mere kinship. This organization is presented nationwide, so it cannot be used as a form of organization as a background of Papua. However, this organization is supported by pillars of each region to form a familiarity, introductions, and friendship in the form of both emotional kinship and rational cooperation.

Particular Bugis family does not pay attention to the importance of education. Especially for traders who inhabit areas of the market and economically well-established without the need to take the path of education. With good economic level as if education is not essential; this also includes children that the parents sent to the island of Java to pursue higher education. Some of them had to go home because those sons were not serious about learning. It is also due to the money transfers and adequate facilities so as not to foster learning ethos to accomplish achievements in the field of education. Finally, they do not have any formal 
qualifications in education. It is the factor that encourages them to remain in economic activity. However, this does not mean that all traders then make their sons and daughters remain to be entrepreneurs. In some other phenomena, instead, they subsequently provide the best education for their children and then they chose to become employees in government agencies or private. Some wholesalers even prepare better education for future generations; although it is still in the economic environment and is not intended to be an employee or employees. Besides, they encourage children to master the skills of modern business. When the time comes, they pass on the business to continue on a larger scale.

While the Bugis community who had activities in the field of education was not living in Papua since the beginning; they came to Papua after completing higher education in place. Some of them moved to Papua because of promotion, placement, and recruitment. Educational qualifications of Papuans not following the criteria set forth in Jakarta making a shortage of applicants for staffing. This vacancy is filled by residents of other islands who have completed education. While universities in Papua only provide administrative personnel; and higher education has not been explicitly established to produce graduates who meet specific qualifications such as a master of lecturers, and health workers.

Migrating to the Bugis community is known as sompeq. It is one way to obtain experience. Both in economic affairs, knowledge and learn the affairs of life directly in the field. In the category of sompeq to gain experience, the subject will someday return to their hometown, in contrast to subjects who migrate for some reason such as siri'(shame) or sociopolitical affairs. They subsequently chose to leave home and never return. Owned properties were later then sold and build a new life and a new family on the ground that they choose by themselves.

Similarly, for a career; they both concerns in government and building a business. They are trying to maintain what has been achieved in the land where they migrated to and do not longer try to get back. As for the relationship with the parents' land, it is still maintained emotionally and tradition, no longer trying to go back and continue the life built on the land of the migrated. Thus, the relationship to build is no longer based on the ancestral lands but rather start from where he/she earns a living. Thus the loyalty he or she has always fought for is where he/she sets foot for a new life. 
Relationship with ancestral lands is merely in the emotional aspect; no longer willing to return. Meanwhile, when death picks up, they chose to be buried in the land where they migrated. It is precise that the land where they migrate would become their homeland. It is not going to, subsequently, have to burden the family to take care of his body and return it to the land of Bugis. It is precise while in the migrated land, the land on which they build a life referred to homeland even though it is not their homeland. Thus, the totality of life which runs entirely devoted to areas inhabited. They are no longer put forth the aspects of the descendants but rather to build for a future life where the next descendants will obtain a source of living of occupied today.

Maritime tradition is an integral part of the tradition of the Bugis. The skills to make boats, fishing equipment, and also sailing is a skill passed down through generations, from generation to generation. Legal norms then follow this tradition. Skills that are engaged to be a part of life itself; so, religion-culture always become part of the adaptation of the latest developments. The existence of the Bugis community reaches out to the outer islands of Papua namely Yanbeser, Agats, and Arguni. Besides, they already reside in Greater Sorong, Jayapura, and other city port. They are then becoming one part of the economic dynamics of the community; but not only trading but becoming one part of society in the real sense. Since the arrival in the place, they are no longer had to leave and even participated in the development to the present day.

\section{Madura and Harmony of Ethnicity}

Specifically, the community of Madura does not refer themselves the same as the Java community. Geographically it is not fused between Java and Madura. Madura economic activity is in the field of food and barber services. These two areas, to be more specific, are to be a part of their daily activities of the business. However, one thing that needs attention is the emotional relationship between Madurese with their religious teacher in the place of origin that does not necessarily cut off. They would maintain contact, and even regularly, they would visit their teachers on the island of Madura. The blessing of teachers is part of the spirituality maintained. Thus they would still in need to consult with the teachers when doing something as well as a sign of gratitude for what he/she has gained in the workplace. Back to the homeland or parents land at the time of Idul Fitri (the end of 
Ramadhan) or other religious holidays, these are a necessity that needs to prepare.

Madurese community is the people who originated from Islamic boarding school environment that their understanding of theological becomes the dominant part in carrying out their activities - especially those living in Sorong completed their secondary school education. Even among them, there are Madurese completing their undergraduate education before moving to Papua. Then some of them continue to pursue graduate studies. With the level of religious education and religious like this, it becomes an opportunity for them to master the knowledge of religion. Education became a major factor so that in any chosen profession, the occupied areas of work, education should remain becoming the primary benchmark.

Although different from the Javanese, Madurese community still has an emotional closeness with them. Thus in some ways, they would still refer to as part of the Java community. In communities in Papua, Madurese community is indivisible socially with Java. To not call it one community, Madura community is only differing in the language of the Java community. For identity and also a view of life, they both have some similarities, though not entirely well worth it. It is because administratively, Madura community puts into groups for the division of East Java province. Thus to mention the origin of the area is sometimes interpreted as a form of similarity between Madura and Surabaya as a region which despite having a different ethnic identity to each other.

The seniority system is practiced as well as a vehicle for helping each other. For subjects who had just come in and made a living in Papua, they are guided and assisted by the first successful entrepreneurs living in that particular land. Once he/she is capable of doing activities on its own and independent, then that newcomer will be in charge to guide newcomers to come. Kinship system takes place in two ways, work, and regions of origin. The senior who then monitor the progress of the business carried on by the juniors. At the same served to determine the market price mechanism. In Sorong city, barbers are united into a community. It also became union organizations to maintain competitive prices so that it will not harm each other in the presence of a price war. Although it does not require approval, the opening of a barbershop would be supervised concerning layout, services, and also the determination of the agreed price. It is the desire to build a business without sacrificing the relationship. The feeling of malo (ashamed) always prioritized in order to maintain dignity and self-esteem. 
Thus, one's actions can only be a stigma for groups and tribes. Thus they would always try to avoid negative behavior and violate the law. In this region, the unity of the group becomes a weapon in the form of "to remind each other and maintain it". Thus, this is forming a desire always to behave well.

The Madurese community incorporated in the Ikatan Keluarga Jawa Sunda dan Madura (IKASWARA). This organization was established in the compote and driven in a particular environment. Each region gets to choose the form of organization. Although mentioned as a stand-alone ethnic, it still incorporated in a more extensive collection of Java. By the merger of the Madurese in larger groups with the mention of Java, then there would be established a social harmony on a broader scale. No longer seen as Madura as an island that geographically located in a place different from Java but has become part of its own that helped establish Javanese culture in transmigration areas.

\section{Migrant and Their Identity in Residing Other Home}

This study shows the religious factor with the identity of Islamic values that have always been shown merely as a diversity of society that meets with other community. At the same time, it becomes part of the sign in the association between communities in the collection of many people surrounding it. With a population of Protestant and Catholic, religion is not a major issue; where in Papua, religion is seen as a purely personal choice and not a communal concern. Even within a single family, there may be a different religion. Indeed, they keep each other together and even lived in the same houses, although with different religions. Thus, if it is in fact that even in the smaller context, they can mutually accept the difference, let alone in the larger scale of the society. Differences in religious choice are not an obstacle to the interaction in the community. Bugis and Madurese communities still maintain their religion even though they have a choice over different religions. Respectively still practice their religion freely and without hindrance from the other party.

Bugis community in inhabiting Papua, they started from economic activities; but did not stop there. Then they began to develop educational aspects. Some of the alumni of Darul Dakwah wal Irshad (DDI) in South Sulawesi founded madrasah (Wekke et al. 2019). Starting in Timika, and then grew in Jayapura and Sorong. This movement was done to meet the needs of the community of Bugis for the sole purpose of religious 
education. While religious education held in Papua tended to be typically according to Javanese and Sundanese culture. With the development of the DDI madrasah (school), this will be a means of instrumental in confirming such awareness of the principal values of Bugis. Some public figures that have a historical and emotional relationship with DDI sent their children to study in Mangkoso, madrasah center of DDI. Similarly, the DDI schools spread across South Sulawesi.

However, for the trader, there are a few people who see education as an action that is just a waste of time. If the Bugis people sometimes overlook education and prioritize economic aspects, then it would not like this with the Madurese community. They make education, especially religious education, as a key principle. Although not specifically in managing educational institutions, the activity of a small-scale study is still being done to reinforce faith. The two communities have looked at education in such different ways. For the people of Madura, education is precisely the individual duty to improve the understanding of religion.

In contrast to the Bugis community, education is nothing but a mere economic activity. So when the economic establishment has been achieved, then education is no longer needed; though the finding of Lammarino and Marinelli education is seen as the social capital for the people who migrate. They require a formal legitimacy to maintain a position in life occupied (Lammarino and Marinelli 2014).

Natural conditions in the form of coastal and mountainous are not giving much of choice. Fishers and farmers are two primary professions. Meanwhile, the arrival of the Bugis and Madura then take advantage of this opportunity to become a trader between islands and provide services such as barbers or tailors. The existence of both later became a part of the economic activity that is dynamically going side by side with the development of society. There are changes to the Papuan people who have had a long journey interaction with the community of Bugis and Madura. In contrast, some areas are isolated and do not get much attention the traders experienced a shortage in the distribution of goods. Thus, the arrival of Bugis and Madura community is seen as part of that event that supports the economic viability.

Maritime tradition has brought together the community of Bugis and Madura. However, because of the sea, they have a different attitude. In the economic activity, the Bugis people, making inter-island trade jobs as part of the economic movement; while the community of Madura would 
make a profession of being fishermen. It is related to the acquisition of skills to build a boat and maintaining the equipment; where we can see the broad market in Teminabuan, South Sorong controlled by Bugis traders. While the community of Madura tends to be retail traders and distributing goods within limited circles, this type is also obtained in Kaimana, Tambrauw, and Waisai, Raja Ampat. Cooperation to beneficent for both parties brought to the trading within a broader scale. It does not just to reach the port area, but also to the inland. Each of them plays a different role but remain mutually strengthening each other.

The cultural system became part of the indivisibility of social activity. Geertz explains that the value of this culture is the one thing that has become a conception of the life that is regarded as something precious (Geertz 1973). If the community of Bugis and Madura are seen with the context of Islamic studies, they retain Islam as a part of life. It is precisely this value, which is then used as the identity of which is not less relevant to their lives. However, the Bugis people, customs, and Islam integrated into life. One of the crucial principles is when living overseas; it is called sumangeq, which can be interpreted as survival. With this principle, they are trying to maintain what they have, achieve what will be achieved, and interact with the owner of the land where they stay for the migration. Gonggong explained that sumangeq could be interpreted as being not abstract but is owned directly by the owners of culture. Sumangeq will be the glue of life and at the same time knitting the differences that exist in dealing with sufferings and successes (Gonggong 2003).

Meanwhile, for the people of Madura, Islam and culture do not become an integrated part of each other. Their tendency to Islamic tradition influenced by Arab culture or from the Middle East. In a term stated by Rumahuru, this practice is then referred to as the Islamic Sharia and Traditional Islamic (Rumahuru 2012). Concerning the environment, an individual of Bugis is trying to bind themselves to the social situation. If agreed, they would then try to get together in the environment to attain peace and happiness in life. Uphold these Bugis values do not mean that they would isolate themselves from the environment. The environment for the Bugis is an important part that must be maintained. Social layers have become another concern, so sometimes people of Bugis seek to occupy the position and play a role by the place obtained. Chabot, in his study, shows that there is an attachment between individual and community. It would be impudence if that particular person does not understand its position and 
therefore cannot understand what to do with its role in society. Failure to understand it is ignorance and behavior like this is an action that ought to avoid (Chabot 1950).

Conditions within the scope of national spirit also always become the community dynamics by the community of Bugis and Madura. The absence of a kingdom and nobility also made the community be open and do not form a system of stratification in society. Equality affected creativity and effort into the value of individual existence. The community would then be merged into Indonesian identity. Plus, the absence of a royal palace in the community or Papua has become another supporter to be alongside carrying one and other shoulders as a guide. The structure formed solely lies in the reference environment. The role in the new place will be formed not as in the community that is inhabited (Vlase and Voicu 2014). Not at the whim of individuals based on blood excellence alone. Mattulada examines this study ex in particular that under Dutch colonial similarity brings a feeling of solidarity, which was then called Indonesia (Mattulada 2011).

The encounter between island residents, the interaction between different people, trade relations, and conversations in topics that is diverse are as a mean in the development of ideas that overstepped the bounds of the territorial and ideological. Thus, in every region of the port in Papua there always grow new social context, the development of thinking has always been the response from other regions, and their materials and new technologies are adapted to suit local needs. Economic and social activity relationship then brought to the latest developments. Likewise, with new ideas, an adaptation of renewal, as well as technology, are transferrable. Such conditions are not the same as what happened to the Chinese immigrants who returned from Canada. They experienced difficulty to adapt to its target environment (Lynn-Ee Ho 2014).

Social role that first came from the economy begins to evolve into the political sphere. In the general election of 2014, some traditional leaders then occupy a good seat in the district and the city as well as at the provincial level. The electability cannot be separated from the religious element and also ethnicity. They were from the beginning has always been a part of maintaining the continuity of ethnic where they came from. Not only in the context of the legislative, executive and even in the region, had some of them subsequently inducted become the deputy mayor, and deputy of the governor. The power obtained is not present in a short time. However, it grew out of the belief existing in each environment. At the 
same time, the implications of the capabilities of the personnel function or individual achievement intended for the public interest (Caldwell 1995). In plain view, it can be seen from the practice of rites performed in daily life. Pelras interprets it as a symbol of integrity and the totality of the individual (Pelras 1971).

Joining the organization has always been an opportunity to reach out and become a stepping stone in reaching out power. If this is moved in the form of real activity, it will form a charisma and political gain higher from time to time. However, some individuals cannot wait to go through a long process and then try to reach the seats in both the legislative and executive. In the end, such efforts will fail because the organization is not used for capacity development but contrary to achieve political gains that cannot be formed abruptly. Eligibility to be inducted into a leader would not only be on a formal scale. However, also because they were from the beginning serving as a consultation place and been instrumental to the distress possessed by their citizens. If they fail to build social relationships with the existing environment, there is no way that they would gain trust from the citizens. As Sunam study which describes the conditions in Nepal, the exploitation and domination of the settlers led to jealousies and turmoil simultaneously with the local community (Sunam 2014).

As for the participation in religious activities, it is solely because of individual needs. They become a sponsor in the construction of mosques, distribute zakat (religious giving), either zakat mal (asset-based giving) or zakat fitrah (giving at the end of Ramadhan), supporting the implementation of madrasah and schools, regularly contributing to the orphanage, and attend learning (taklim) assemblies. Everything is done to satisfy personal obligations. As for the establishment and management of schools or madrasah, it is also because of the needs of the family and the environment. Bugis community migration patterns and the Madurese are not done for the sake of dakwah (Islamic calling). It is just that they perform religious activities as a form of syiar (public communication) and does not make people of other religions as a deployment target of religious messages.

Mosque becomes a place to realize the expectations for the immigrants. In this regard, the community of Bugis and the Madurese make mosques as a means for dialogue, meeting, and interacting with other people. By not submitting his understanding of the practice of Islam, they always join a larger group. Unless in that environment, they build a mosque together with community groups themselves, then the implementation of 
prayer will be adapted to the respective traditions. Mosques also become a meeting point for various groups. By uniting Islamic identity, they subsequently choose to be part of a pluralistic Islamic society with ideology and different schools of thought. However, they always try to contribute and provide assistance in the form of funding and contribution to the implementation of the activities carried out in the mosque regularly. Under these conditions, religion becomes a factor of adhesive and no longer concerned with the base of tribe and ethnicity (Duchene-Lacroix and Koukoutsaki-Monnier 2015).

The mental factor is one part that becomes attitudes and actions for a person to act to be a mirror of his character (Koentjaraningrat 1985). This article discovers that the similarity of character in submission to always be in groups, the adaptation to the demands of society, and attitudes toward time, work, and emotional, making all three of the characters are similar between individuals of Buginese and Madurese. Therefore, these similarities continue to extend the potential for them to maintain such teamwork more easily to be implemented together despite coming from different ethnic. The same social ties also in terms of the diversity of Islam that further strengthen the cooperation. Cooperation structures are built based on the similarity of religion, and traditionally, they see each other within another figure who is also the same in his situation, and that makes an emotional bond to establish.

\section{Conclusion}

This article sees that Buginese and Madurese communities have their character and identity; however, in some part, these two ethnicities quite similar. Their presences in Papua through migration process are one of it. Their ancestors' habit and well known as a fierce sailor as well as openhearted ethnics become they easily adapted in a new place. Among others in terms of economic activity, mastery in the field of politics, and social role in the community are also their similarities in Papua. At the same time with their member capacity and Islamic identity in their new environment where believed by this study as their strong reasons why these two ethnics can survive in Papua. 


\section{References}

Abidin, Andi Zainal. 1983. Persepsi Orang Bugis Makassar tentang Hukum, Negara, dan Dunia Luar. Bandung: Penerbit Alumni.

Acciaioli, Greg. 2009. "Utang Piutang dan Sistem Kekerabatan Struktur Sosial Masyarakat Bugis Perantauan dan Pemasaran Ikan di Danau Lindu, Sulawesi Tengah." In Kuasa dan Usaha di Masyarakat Sulawesi Selatan, eds. Rogel Tol, Kees van Dijk, and Greg Acciaioli. Makassar: Ininnawa.

Ammarell, Gene. 2008. Navigasi Bugis. Trans. Nurhay Sirimorok. Makassar: Hasanuddin University Press.

Berger, Peter L. 1963. Invitations to Sociology. New York: Doubleday.

Caldwell, Ian. 1995. "Power, State, and Society among the Pre-Islamic Bugis." BKI, 151-III: 394-421.

Chabot. Hendrik Theodorus. 1950. Verwantschap, Stannd en Sexe in ZuidCelebes. Groningen: J. B. Wolters.

Chiang, Lan-Hung Nora. 2011. "Return Migration: The Case of the 1.5 Generation of Tawainese in Canada and New Zealand." China Review 11(2): 91-124.

De Jonge, Huub. 1989. "Hubungan Ketergantungan dalam Perikanan di Madura." In Agama, Kebudayaan, dan Ekonomi: Studi-Studi Interdisipliner tentang Masyarakat Madura, ed. Huub De Jonge. Trans. Suparmin. Jakarta: Rajawali Pers.

Duchene-Lacroiz, Cedric, and Angeliki Kokoutsaki-Monnier. 2015. "Mapping the Social Space of Transnational Migrants on the Basis of Their (supra) national Belongings: The Case of French Citizens in Berlin." Identities: Global Studies in Culture and Power 23(2): 1-19. DOI: https://doi.org/10.1080/1070289X.2015.1008000

Geertz, Clifford. 1983. Local Knowledge, Further Essays in Interpretive Anthropology. New York: Basic Books.

Gongong, Anhar. 2003. "Interpretasi Kelampauan: Mencari Makna untuk Melanjutkan Hidup Bersama (Sebuah Pengantar Imaji).” In La Galigo Menelusuri Jejak Warisan Sastra Dunia, eds. Nurhayati 
Rahman, Anil Hukma, and Idwar Anwar. Makassar: Pusat Studi La Galigo Divisi Ilmu Sosial dan Humaniora Pusat Kegiatan Penelitian Universitas Hasanuddin.

Husson, Laurence. 1997. "Eight Centuries of Madurese Migration to East Java." Asian and Pacific Migration Journal 6(1): 77-102.

DOI: https://doi.org/10.1177/011719689700600105

Iammarino, Simona, and Elisabetta Marinelli. 2014. "Education-job (Mis) Match and Interregional Migration: Italian University Graduates' Transition to Work." Regional Studies 49(5): 1-17.

DOI: https://doi.org/10.1080/00343404.2014.965135

Kesuma, Andi Ima. 2004. Migrasi dan Orang Bugis. Yogyakarta: Penerbit Ombak.

Koentjaraningrat. 1985. "Rintangan-Rintangan Mental dalam Pembangunan Ekonomi di Indonesia." In Sosiologi Pedesaan, eds. Sajogyo and Pudjiwati Sajogyo. Yogyakarta: Gadjah Mada University Press.

Kuntowijoyo. 1980. "Social Change in an Agrarian Society." Dissertation. Columbia University.

Ley, David. 2010. Millionaire Migrants: Trans-Pacific Life Lines. Oxford: BlackWiley.

Lynn-Ee Ho, Elaine. 2014. "Middling Chinese Returnees or Immigrants from Canada? The Ambiguity of Return Migration and Claims to Modernity." Asian Studies Review 38(1): 36-52.

DOI: https://doi.org/10.1080/10357823.2013.853167

Mattulada. 1998. Sejarah, Masyarakat, dan Kebudayaan Sulawesi Selatan. Ujung Pandang: Hasanuddin University Press.

Mattulada. 2011. Menyusuri Jejak Kehadiran Makassar dalam Sejarah. Yogyakarta: Penerbit Ombak.

Mintaroem, Karjadi, and Mohammad Imam Farisi. 2001. "Aspek SosialBudaya pada Kehidupan Ekonomi Masyarakat Nelayan Tradisional (Studi pada Masyarakat Nelayan Tradisional di Desa Bandaran, Pamekasan)." Jurnal Studi Indonesia 11(2): 107-28. 
Naim, Mochtar. 1972. "Merantau dan Pengaruhnya terhadap Pembangunan Daerah." Prisma No. 4 June, 36.

Pelras. Christian. 1971. "Hierarchieet Pouvoir Traditionnels en Pays Wadjo.” Archipel 1: 169-91.

Poelinggomang, Edward L. 1991. "Proteksi dan Perdagangan Bebas: Kajian tentang Perdagangan Makassar pada Abad ke-19.” Dissertation. Vrije Universiteit Amsterdam.

Pribadi, Yanwar. 2018. Islam, State and Society in Indonesia: Local Politics in Madura. London: Routledge.

Rachmat, Zainabbinti. 1977. "Etnis Bugis di Kampung Melayu Pandan Johor, Negara Bagian Malaysia.” Thesis. Universitas Hasanuddin Ujung Pandang.

Rahman, Nurhayati. 2006. Cinta, Laut, dan Kekuasaan dalam Epos La Galigo. Makassar: La Galigo Press.

Reuveny, Rafael. 2007. "Climate Change-Induced Migration and Violent Conflict.” Political geography 26(6): 656-73.

DOI: https://doi.org/10.1016/j.polgeo.2007.05.001

Ricklefs, M. C. et al. 2013. Sejarah Asia Tenggara dari Masa Prasejarah sampai Kontemporer. Jakarta: Komunitas Bambu.

Rumahuru, Yance Zadrak. 2012. Islam Syariah dan Islam Adat. Jakarta: Badan Litbang and Diklat Kementerian Agama RI.

Sani, M. Yamin. 2005. "Migrasi Inovatif Orang Bugis." In Manusia, Kebudayaan, dan Pembangunan di Sulawesi Selatan. Makassar: Dinas Kebudayaan dan Pariwisata Provinsi Sulawesi Selatan.

Soleh, Badrus. 2010. "Peranan Bugis Pendatang dalam Proses Islamisasi Bagian Timur Indonesia: Kasus Konteks Sejarah Ambon.” In Diaspora Bugis di Alam Melayu Nusantara, ed. Andi Faisal Bakti. Makassar: Ininnawa.

Subaharianto, Andang et al. 2004. Tantangan Industrialisasi Madura, Membentur Kultur, Menjunjung Leluhur. Malang: Bayumedia. 
Sunam, Ramesh. 2014. "Marginalised Dalits in International Labour Migration: Reconfiguring Economic and Social Relations in Nepal.” Journal of Ethnic and Migration Studies 20(12): 2030-48.

DOI: https://doi.org/10.1080/1369183X.2014.948393

Vlase, Ionela, and Malina Voicu. 2014. "Romanian Roma Migration: The Interplay Between Structures and Agency." Ethnic and Racial Studies 37(13): 2418-37.

DOI: https://doi.org/10.1080/01419870.2013.809133

Wekke, Ismail Suardi, and Sanusi Hamid. 2013. "Technology on Language Teaching and Learning: A Research on Indonesian Pesantren." Procedia-Social and Behavioral Sciences 83: 585-89.

DOI: https://doi.org/10.1016/j.sbspro.2013.06.111

Wekke, Ismail Suardi. 2012. "Islam dan Adat dalam Pernikahan Suku Bugis di Papua Barat." Thaqafiyyat: Jurnal Bahasa, Peradaban dan Informasi Islam 13(2): 307-55.

Wekke, Ismail Suardi. 2014. Mimbar, Tindak Tutur, dan Harmoni: Penyuluh Agama dalam Pesan Keagamaan di Sorong. Sorong: Pusat Penelitian dan Pengabdian kepada Masyarakat STAIN Sorong.

Wekke, Ismail Suardi. 2016. "Religious Education and Empowerment: Study on Pesantren in Muslim Minority West Papua.” MIQOT: Jurnal Ilmu-Ilmu Keislaman 37(2): 374-95.

DOI: http://dx.doi.org/10.30821/miqot.v37i2.88

Wekke, Ismail Suardi, Ngesti Wihayuningtyas, Payiz Zawahir Muntaha, and Mukhlis Mukhlis. 2019. "Leadership Typology of Traditional Islamic Boarding School in Eastern Indonesia: Learning to Lead from DDI Mangkoso.” INFERENSI: Jurnal Penelitian Sosial Keagamaan 12(2): 331-48.

DOI: http://dx.doi.org/10.18326/infsl3.v12i2.331-348

Wertheim, W. P. 1964. "Society and Composite of Conflicting Value System.” In East-West Paralles: Sociological Approaches to Modern Asia. The Hague: W. Van Hoeve, Ltd.

Wiyata, Latief. 2002. Carok: Konflik Kekerasan dan Harga Diri Orang Madura. Yogyakarta: LKiS. 
Wiyata, Latief. 2003. Madura yang Patuh? Kajian Antropologi Mengenai Budaya Madura. Jakarta: CERIC-FISIP UI.

Yusuf, Muhammad, and Wekke, Ismail Suardi. 2013. "Pemikiran Gender Ulama Bugis.” In Bugis dalam Peradaban Melayu. Tanjung Malim: Universiti Pendidikan Sultan Idris. 